\title{
RUSSELL AND THE OTHER DORA, 1916-18
}

\author{
ANDREW G. Bone \\ Russell Research Centre, McMaster U. \\ Hamilton, oN, Canada L 8s 4L6 \\ BONE@MCMASTER.CA
}

During the First World War Russell frequently complained about unwarranted encroachments by the wartime state on the sphere of individual freedom. He experienced such encroachments very directly. The Defence of the Realm Act (DORA) was the legal instrument through which most official reprisals were visited on him-punitive measures arising from his dogged support for conscientious objectors and a negotiated peace. Under this emergency legislation he was twice convicted and had his freedom of movement curbed. This harsh treatment is well known, but the literature on Russell has not yet systematically examined his relationship with this "other DORA". Using the Russell Archives, his Collected Papers, and government records in the UK's National Archives, this paper seeks to establish the legal, administrative and political contexts in which he was prosecuted and sanctioned extra-judicially, and where he sometimes benefitted from DORA's formidable powers being set aside.

\section{INTRODUCTION}

$7 \mathrm{n}$ First World War Britain the acronym "DoRA" (for Defence of the Realm Act) was frequently anthropomorphized into a "cruel and capricious maiden who at the snap of her fingers could close down a newspaper, requisition a ship, or prohibit whistling for cabs" I- or even, as Arthur Marwick's classic social history of the

I Marwick, The Deluge (1965), p. 36. 
Home Front might have added, hound and ultimately imprison the Hon. Bertrand Russell, one of the most distinguished living fellows of Trinity College, Cambridge. Hastily enacted after the outbreak of war but the product of years of (inconclusive) deliberations, ${ }^{2}$ DORA was, in essence, a "skeleton" statute, with an administrative frame fleshed out by an ever-expanding body of Defence of the Realm Regulations (DORRs). ${ }^{3}$ Such extensive delegation of legislative authority (by Order in Council) is integral to modern public administration. It was far less characteristic of early twentieth-century governance, although not so atypical of British practice as presumed by those who detected in DORA a recrudescent Tudor despotism or an alien, Continental bureaucratism. Together with DORA, two other contentious measures were forged into a menacing trident of coercive wartime controls. In July I9I5 the Munitions of War Act imposed strict workshop discipline and curtailed the free movement of labour, while the following March the legislation of conscription overturned the supposedly venerable practice of volunteer military service. The extraordinary reach of DORA probably made it the most potent statutory symbol of official resolve to subordinate, if necessary, all aspects of social, economic and political life to the imperatives of total war. ${ }^{4}$

2 See Rubin, "The Royal Prerogative or a Statutory Code? The War Office and Contingency Legal Planning, I885-1914" (I987).

3 A single-clause Defence of the Realm Act came into force on 8 August 1914, four days after Britain declared war on Germany. Its scope was broadened by an amending law of 28 August before both statutes were superseded on 27 November by the Defence of the Realm Consolidation Act-the legislation to which the acronym "DORA" therefore usually refers. Two amendments to this third DORA were carried in March I9I5: one curbed the jurisdiction of the military in DORA cases; a second anticipated the comprehensive war production and civilian manpower controls ushered in four months later by the Munitions of War Act. Four other, more narrowly conceived DORAs were enacted subsequently. These selectively authorized the state purchase of the liquor trade, protected the Crown against the loss of public money expended on requisitioned property, penalized speculative trading in foodstuffs, and affirmed the purchase price for a consignment of beans, peas and pulses. But the majority of controls and prohibitions pertaining to the defence of the realm were effected by DORA's auxiliary code of regulations. An initial batch, 3I in all, was introduced on I2 August 19I4, and after 85 more Orders in Council-adding new powers and amending others-some 260 DORRs were in force by the war's end.

4 See, for example, this entry from BEATRICE WeBb's diary, which is striking because she was far from unfavourably disposed, as a Fabian socialist, to the steady forward march of war collectivism: "The Munitions of War Act and the Defence of the Realm Act, together with the suppression of a free press, has been followed by the Cabinet's decision in favour of compulsory military service. This decision is the last of a series 
Dismayed by the transformation of the state into an instrument of compulsion rather than of the orderly progress achieved by the New Liberal welfare reforms of the pre-war era, Russell and other hostile voices lambasted these war measures as perversely ironic by-products of a vaunted fight for freedom. DORA's foes protested not only the suppression of anti-war dissent but also, inter alia, the encroachment of "competent military authorities" " on civil jurisdictions, internment without trial (DORR I4B), and the punitive treatment of women arising from bungled attempts at reducing venereal disease in the armed forces (DORR 4OD). ${ }^{6}$ One overarching objection to DORA targeted the elasticity of its ordaining powers, which had been "so construed as to include within their ambit almost every portion of our social and civil life". ${ }^{7}$ Some draconian DORRs appeared only tangentially connected

of cleverly devised steps, each step seeming at once harmless and inevitable, even to the opponents of compulsion, but in fact necessitating the next step forward to a system of military and industrial conscription" (I Jan. 1916; Diary 3: 244). KENNEDY has argued that, while seemingly entrenched, voluntarism in recruiting was an essentially Victorian convention (The Hound of Conscience [198I], pp. I-5).

5 For most of the First World War, Home Forces on mainland Britain were split into seven District Commands, for each of which officers with the designation of Competent Military Authority (CMA) were responsible for administering and enforcing DORA. (In July I9I 8 these military districts were made coterminous with those of the police in a reorganization driven less by the requirements of home defence than a perceived need to streamline military aid to the civil power: see Millman, "British Home Defence Planning and Civil Dissent, I917-I918” [1998], pp. 227-8.) CMAs were also appointed in each of the areas (more than 60) into which the District Commands were subdivided, and at the highest levels of the army's political and military leadership the same powers were conferred on members of the Army Council and the Military Intelligence branch of the War Office. Competent Naval Authorities were similarly empowered on the islands off the north-east and west coasts of Scotland and in all major ports and dockyards, while many powers were vested in the civilian bureaucracy - the Treasury and Board of Trade, for example, and such wartime administrative creations as the Ministries of Munitions and Food—as DorA was fashioned into an instrument for marshalling the nation's productive and material resources. As the government department to which the police were ultimately answerable, the Home Office had an understandably central role in the implementation of DORA. If cases with censorship implications (something of particular relevance to the present paper) were brought to the attention of district or area CMAs, they were instructed to report to the War Office, which was bound, in turn, to consult with the Home Office on such matters.

On the DORR I4B and 4OD controversies, see, respectively, Simpson, In the Highest Degree Odious: Detention without Trial in Wartime Britain (1992), ch. 2, and BuCKLEY, "The Failure to Resolve the Problem of Venereal Disease among the Troops in Britain during World War I" (1977).

7 "Defence of the Realm Acts", Parliamentary Debates (Lords), 5th ser., 24 (7 March 
with the stated purposes of the statute. These were not administrative details, so complaints went, but discrete powers warranting their own legislative sanction. This circumvention of Parliament and the corresponding growth of unchecked executive discretion was the second general grievance levelled at DORA. Russell, for example, drew on this strain of criticism in objecting to the imposition, "Behind the Back of the People", of a new DORR $(27 \mathrm{C})$ requiring all pamphlet literature to be passed by censorship authorities before publication. ${ }^{8}$

It was politically prudent for Russell and others to focus on the distortion of hallowed constitutional norms rather than on the rights of an embattled anti-war minority. Yet this critique was slightly artificial, given that an overwhelmingly pro-war Parliament would probably have assented willingly to the embodiment in statutory form of many contentious regulatory powers. A similar point could be made about the courts, which invariably upheld the executive's broad construction of DORA's keynote enabling provision. ${ }^{9}$ Parliamentary sovereignty and the rule of law were nevertheless vigorously championed in wartime Britain by liberals and socialists drawing on a case against bureaucratic, unaccountable, even un-English, government mounted in the pre-war era by the influential conservative jurist A. V. Dicey. ${ }^{10}$ Whereas Dicey was opposed to the drift of Edwardian social policy on ideological as well as constitutional grounds, many of DORA's detractors (including Russell) had previously applauded the judicious

1917): 402-24 (at 4I6). The quoted speaker, Lord Parmoor, was nominally Conservative but also a staunch parliamentary advocate for civil liberties-including those of imprisoned conscientious objectors.

8 "The New Dictatorship of Opinion", prepared in November I9I7 as a leaflet for distribution by the National Council for Civil Liberties (82 in Papers 14).

9 In a handful of cases concerned with property rights and in which the litigation dragged on after the Armistice, the statute's delegating authority was eventually circumscribed (see Rubin, Private Property, Government Requisition and the Constitution, 1914-27 [1994], chs. 6-8). In the heat of war, however, courts at all levels were more inclined to act in the spirit of the landmark majority ruling made by the Law Lords in the case of Rex v. Halliday, which rejected a challenge to executive detention by DORR I4B: "However precious the personal liberty of the subject may be," Lord Atkinson declared, "there is something for which it may well be, to some extent, sacrificed by legal enactment, namely, national success in the war, or escape from national plunder or enslavement" (quoted in CARR, Delegated Legislation [I92 I], p. 30).

Io Most notably, in the chapter on French droit administratif in Dicey's frequently revised and reprinted Introduction to the Study of the Law of the Constitution (1885): see Cosgrove, The Rule of Law: Albert Venn Dicey, Victorian furist (1980), pp. 9I-IO2. 
deployment of state power for progressive ends. ${ }^{\text {II }}$ Yet, responding to the erosion of civil liberties under the cover of a national emergency, they retreated after August I9I4 into a rearguard defence of liberal fundamentals. ${ }^{\mathrm{I} 2}$ Conservative political and legal voices were more comfortable with the maxim that in war, salus reipublicae suprema lex. ${ }^{\mathrm{I3}}$ But they returned to an old line of attack post-war, sensing that the techniques of governance embedded in DORA were not merely "for the duration" but likely to stay and impede the restoration of business as usual in the social and economic spheres. ${ }^{14}$ Russell was an acerbic critic of both DORA in particular and the wartime state in general. But he was also one of DORA's more notable victims. ${ }^{15}$ Certain particulars of his travails with this "other DORA" ${ }^{16}$ will be familiar. ${ }^{17}$ Yet no study of Russell's peace campaigning in the First World War has been dedicated to the emergency legal instruments by which he was repeatedly targeted, or the political and bureaucratic influences on the judicial proceedings and administrative actions against him.

\section{LEGAL ACTION AND INACTION}

Curiously, Russell was quite unperturbed by DORA's initial pursuit. This began in May I9I6 after six members of the No-Conscription Fellowship (NCF) were found guilty under DORR 27 of spreading reports likely to "prejudice recruiting", for distributing a widely circulated leaflet of which Russell was the anonymous author (see Papers

II See Papers I2: xxxiii-although Russell was not in sympathy with the social theory undergirding the New Liberal programme, tinged as it was with the philosophical idealism he had rejected (ibid.: 3I). In I9I0 Russell published a stinging attack on Dicey - not on the legal thinker's anti-statist animus but, rather, on his equally forthright opposition to women's suffrage (ibid.: 27).

I2 See FreEden, Liberalism Divided (I986), ch. 2.

${ }^{13}$ I.e., the welfare of the state is the highest law.

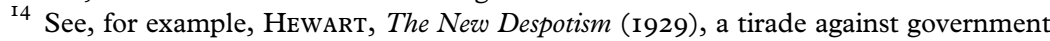
by bureaucracy written by a Lord Chief Justice who as a wartime Solicitor General had been responsible for upholding the very powers he came to disparage.

I5 See Appendix for descriptions, with quotations, of DORRs used or contemplated for use against Russell, and details of their application to him.

${ }^{16}$ Russell first met Dora Black, his second wife, in I916 (see SLBR 2: 189).

${ }^{\mathrm{I}}$ In addition to Papers $\mathrm{I} 3$ and I4, see Russell, A Pacifist at War, ed. Griffin (2014); Clark, The Life of Bertrand Russell (1975), pp. 282-304, 337-44; Monk, Bertrand Russell: the Spirit of Solitude (1996), pp. 463-82, 520-4; and Vellacott, Conscientious Objection: Bertrand Russell and the Pacifists in the First World War (2015), ch. 7 and pp. 223-36. 
13: 370). When Russell confessed in a letter to The Times ${ }^{18}$ that he had written the so-called Everett leaflet, ${ }^{19}$ the authorities were more or less obliged to prosecute him as well. He too was charged under the same clause of DORR 27 and tried at the Mansion House, where on 5 June he was found guilty and fined $£$ IOO by the Lord Mayor of London. Russell had rather goaded the authorities into acting against him and was blasé about his punishment-even though he did (unsuccessfully) appeal his conviction a few weeks later.

While not wanting others penalized for what he had written, Russell also welcomed the publicity of a trial in open court. Frustrated that no verbatim record of the proceedings seemed to have been made by any NCF members in attendance, he complained the next day to his friend and political associate Clifford Allen that "absolutely the only point of making a speech and defending myself was to have it reported" (6 June 1916; Papers 13: 377). Notwithstanding this apparent oversight, the NCF also appreciated the propaganda value of trial proceedings. After eight members of its national committee were convicted in another "prejudicing recruiting" trial three weeks before Russell's, the organization's weekly newspaper, The Tribunal, expressed satisfaction that the substance of the pamphlet at the centre of that case, Repeal the Act, had been "made known in every home in the country, and to every soldier who reads a daily paper." ${ }^{20}$ Representing himself, Russell did not attempt a technical defence but simply and defiantly reiterated the message of the leaflet that had brought him to trial — with its impassioned justification of absolute freedom of conscience and blistering attack on the British Government's punitive treatment of conscientious objectors (c.o.s).

Not surprisingly perhaps, the authorities began to question the wisdom of laying charges in such DORA cases. "Prosecutions of authors ... are not much use", minuted Sir Ernley Blackwell, chief legal assistant at the Home Office on I4 June I9I6. "They go back to their press and print leaflets which keep within the law but do just as much to instigate active resistance to the Military Service Acts as would leaflets containing one or two expressions which would justify a conviction

I8 “Adsum Qui Feci” [I'm the one who did it], I7 May 1916, p. 9 (54 in Papers 13).

${ }^{19}$ I.e., Two Years' Hard Labour for Refusing to Disobey the Dictates of Conscience (1916; 19 in Papers 13), protesting the plight of Ernest F. Everett.

20 "The Result of the Government Prosecution", no. Io (25 May I9I6): I. 
under R. [DORR] 27." "I Instead, Blackwell favoured a more unrestricted application of another DORR, 5I, which authorized the seizure and destruction of objectionable literature as well as the confiscation of printing equipment.

Slightly uncomfortable with this draconian power at his disposal, the Liberal Home Secretary, Herbert Samuel (Russell's friendly sparring partner on $\mathrm{BBC}$ radio in the $195 \mathrm{Os}^{22}$ ), instructed that anti-war material be suppressed under DORR 5I only if it had featured already in a successful DORR 27 prosecution. ${ }^{23}$ Accordingly, both Two Years' Hard Labour and Repeal the Act were added to a Home Office "Hostile Leaflets" circular, which had been compiled in March I9I6 and was regularly updated with instructions for local constabularies to seize and destroy stockpiles of embargoed literature in their jurisdictions. ${ }^{24} \mathrm{~A}$ published record of Russell's trial (56b in Papers I3) - an NCF notetaker had been present after all-suffered the same fate. Ironically, this pamphlet (Rex v. Bertrand Russell) was placed on the "Hostile Leaflets" circular not because of anything newly "prejudicial", but

${ }^{21}$ HO 45/10742/263275/179 ("War: Anti-Recruiting and Peace Propaganda, Meetings, Marches and Speeches"), National Archives, UK.

${ }^{22}$ When they frequently sat on the same panel of the ввс Overseas Service's longrunning discussion programme, London Forum. See, for example, 38, 53, 67 in Papers 26 (forthcoming); 5 in Papers 28; 45 in Papers 29.

${ }^{23}$ See Bone, "Beyond the Rule of Law: Aspects of the Defence of the Realm Acts and Regulations, I9I4-I8" (I994), p. I47. Samuel explicitly ruled out the suppression of another Russell pamphlet, Why Not Peace Negotiations? (6I in Papers I3), not only on these narrow legal grounds but also because it had never been intended "to use the powers of the Executive to prevent people advocating negotiations for peace, inconsistent with the national purpose though such advocacy is" (to Sir Edward Troup, 30 Oct. I916, HO 139/23/96 [Pt. 2], National Archives, UK).

${ }^{24}$ See also n. 66. A half-hearted attempt to bring DORR 5I into closer conformity with the rule of law had been made by the introduction of DORR 5IA in May I9I5. DORR 5IA offered the owners of confiscated literature (or printing machinery) the chance of redress if they could demonstrate to a magistrate "why the articles so seized should not be destroyed". But this entitlement to restitution was distinctly flawed, for injured parties appeared in court burdened with an à priori presumption of guilt. A semblance of due process was eventually added to the administration of DORR 5I as well, by the establishment in January I9I8 of a Home Office Advisory Committee to make recommendations about publications confiscated by the police. This body was set up in the first instance to adjudicate on a large backlog of dissenting literature seized in a flurry of recent raids. Although this quasi-judicial tribunal was chaired by a High Court Justice, it was nevertheless attacked for merely providing cover for the suppression by administrative order of material never condemned in a court of law (see BONE, pp. I82-6). 
because it contained Archibald Bodkin's case for the prosecution, which quoted at length from the condemned Everett leaflet. Even though the sole objective had been to publicize Russell's "defence", the Crown counsel's address was added to the pamphlet, Russell explained to Liberal MP C. P. Trevelyan (a colleague in the Union of Democratic Control [UDC]), because "we thought it unfair to print it without the prosecution" (22 Oct. 1916; Papers 13: 378).

Sir Charles Mathews, Director of Public Prosecutions (DPP), concurred with Blackwell's advice that "the day for the prosecutions of individuals ... is past, and that it is to the seizure and destruction of seditious and pro-German 'literature' our efforts ought to be directed in future." Mathews was commenting on a speech by Russell in Cardiff on 6 July I9I6 (63 in Papers 13), a transcript of which had been sent to the Home Office by a reporter from that city's Western Mail. ${ }^{25}$ Russell fully expected to be charged over this address, which he commenced by saying, "I do not believe there is now any good and valid reason why this war should continue to be prosecuted." In forwarding the relevant papers to the DPP, Sir Edward Troup, permanent secretary to the Home Office, suggested that virtually the entire speech could be construed (under DORR 27) as "likely to cause disaffection". Troup singled out as especially egregious a passage about Russian war aims in the Near East, which was also likely under the same DORR "to prejudice His Majesty's relations with foreign powers". ${ }^{26}$ Nevertheless, he was dubious about proceeding against Russell, since he would mount "a clever defence, and would publish it as a pamphlet." Mathews agreed that a conviction could be secured, but at the cost of giving "publicity to opinions which, but for the prosecution, would

${ }^{25}$ The newspaper's slanted coverage of the Cardiff speech ("Called a Traitor", 7 July I9I6, p. 3) also quoted two jingoistic hecklers: Lovat Fraser, an associate of press baron Lord Northcliffe, and Captain W. H. Atherley-Jones, a Welsh army officer. A Home Office review was prompted by the latter's dispatch of excerpts from Russell's address to a national newspaper, the Daily Express (see Papers I3: 420-I).

${ }^{26}$ The following passage is highlighted in the transcription of Russell's speech obtained by the Home Office: "The Russian desire to possess Constantinople is, I think, the main cause of the continuation of this war now. There is one other cause-though of this we cannot be sure-which is much more sinister than the Russian desire for Constantinople. You will notice in those terms read in the Express that the Germans suggested autonomy for Poland. Autonomy for Poland is not a thing that the Russian Government desires. I do not know, but I think it is not unlikely that one of the things we are fighting for now is to prevent the liberty of Poland" (Papers 13: 428). 
remain stillborn - a remedy which ... is worse than the disease." But the DPP did want the Official Press Bureau to instruct newspapers to refrain from reporting public meetings attended by Russell, and any pamphlets or leaflets authored by him to be pre-emptively confiscated-with the Cardiff speech used as justification should such brusque action be publicly challenged. The possibility of again prosecuting Russell, however, was definitively ruled out when the Home Secretary minuted that this would be "inadvisable". ${ }^{27}$

The same hesitancy about indicting Russell was evident a few months later when it became clear that his open letter to Woodrow Wilson-imploring the American President to broker peace between the European powers ( 2 in Papers I4) - had been smuggled out of the country before excerpts from it appeared in the New York Times and other American newspapers. ${ }^{28}$ The British Government had a locus standi in the form of DORR 24, which prohibited non-postal communications overseas. Although not conceived as a weapon in the battle against dissent-DORR 24 was a bona fide counter-espionage measure effected by an early DORA Order in Council-it was easily adaptable to such a purpose. Russell certainly anticipated "trouble over my letter to Wilson", he told Lady Ottoline Morrell on II January I9I7. ${ }^{29}$ Reviewing the cases against both Russell and C.P. Trevelyan (who seemed to have used similarly furtive means to send a message to President Wilson), Sir Ernley Blackwell had "little doubt that the letter was written by Russell and sent by special messenger in contravention of R. [DORR] 24. The same is probably true of Trevelyan's." But he advised against searching for the requisite proof because neither letter contravened DORR $27 .{ }^{30}$

${ }^{27}$ Mathews to Blackwell, 28 Aug. 1916; Troup to Mathews, 25 Aug. 1916; Samuel (minute), I Sept. I9I6, Ho 45/IIOI2/314670 ("War: Pacifist Activities of Bertrand Russell"), National Archives, UK. Photocopies from this bulky Home Office file were obtained by the Russell Archives and accessioned as RA Rec. Acqs. 903c-k.

28 "Mysterious Girl Brings Russell's Peace Plea Here", 23 Dec. I9I6, pp. I, 3. The letter had not been transported to the United States by any "mysterious girl"although the sister of Russell's former American lover, Helen Dudley, was suspected of thus conveying it by both British authorities and Russell himself (see Auto. 2: 3I). The courier was actually Philip Sargent Florence, with whom Russell was acquainted through C. K. Ogden, editor of The Cambridge Magazine (see Papers I4: 9).

${ }^{29}$ No. I,513, Morrell papers, U. of Texas at Austin (copy in RA).

${ }^{30}$ Blackwell (minute), 20 Jan. I917, HO 45/11012/314670/12. 
This cautious counsel reflected sensitivity to the effects of any prosecutions on neutral American opinion, although rather less to the outraged feelings of Russell's domestic critics. In a stern editorial rebuke entitled "The Pacifist at Large", The Morning Post pilloried Russell as a person "so troublesome that the Government have been obliged to restrict the range of his activities." ${ }^{31}$ Readers of this Conservative daily's leader might have inferred that Russell's "activities" needed to be checked further in light of his wilful and "unpatriotic" evasion of the censorship and the "signal disservice" to his country he had performed by exaggerating for anti-British American audiences the extent of peace sentiment in Britain. Russell was attacked not only in the right-wing press but also in the House of Commons, where the new Home Secretary, Sir George Cave, had to field a pointed question from disgruntled Conservative backbencher J. G. Butcher, one of the anti-war movement's most vocal and persistent critics. ${ }^{32}$

Blackwell's legal reasoning, however, makes it surprising that no DORR 24 charge was laid against Russell in respect of "For Conscience Sake", an article which had accompanied the letter to Wilson on its clandestine transatlantic journey and was then published in The Independent, a pro-neutral New York weekly (6 in Papers I4). This piece attacked the British Government's civil liberties record and Russell's own harsh treatment by DORA. For good measure, it also reprinted all of the judicially condemned Everett leaflet. In this instance, official inaction may be explained by a loophole in DORR 24, which was closed in July 1917 by extending its coverage from "letters" and "written messages" to "memoranda". ${ }^{33}$

${ }^{31}$ II Jan. I9I7, p. 6. The quoted passage refers to the "prohibited areas" order served on Russell by the War Office on I September I9I6 (see pp. II I-I4 below). For Russell's reply, see idem., I5 Jan. I917, p. 8 (7 in Papers I4).

32 "Press Censorship", Parliamentary Debates (Commons), 5th ser., 90 (12 Feb. 1917): 263-5.

${ }^{33}$ Since December I9I6 a related DORR, 24B, had proscribed the unlicensed export of printed matter to neutral or enemy states and was invoked in the case brought against UDC leader E. D. Morel in September 1917 (see n. 77 below). Even before the promulgation of DORR 24B (in July I916), an export embargo was placed on The Tribunal. Although this legally questionable ban on its circulation overseas (see BoNE, pp. I64-6) was far from the gravest threat to the newspaper's survival (see n. 58 below), it persisted through and beyond Russell's editorship during 1917. The same prohibition was applied to other dissenting publications and, more contentiously (in March 1917), to the leading Radical-Liberal weekly, The Nation (see HavigHuRsT, Radical fournalist: H. W. Massingham [1974], pp. 250-6). 
Russell had a third narrow escape from DORA's clutches after he attended and briefly addressed a storied gathering of anti-war socialists in Leeds on 3 June 1917. This demonstration of militant Labour's solidarity with the Russian Revolution made the British Government jittery. The meeting might have been prohibited under DORR 9A, and follow-up events in Glasgow and Birmingham were cancelled under this restriction of the right of public assembly. ${ }^{34}$ In the aftermath of the Leeds Convention, the DPP advised against laying any charges, even though some speakers may have contravened DORR 42. (There had been calls for an immediate peace and the establishment of British Soldiers' and Workers' Councils in emulation of the Russian Soviets.) Russell, it seems, was not among those deemed to have spoken seditiously. Both he and James Ramsay MacDonald, a future Labour Prime Minister, had been "more careful", the DPP's office reported (quoted in Papers I4: 173). Indeed, Russell restricted his short speech in support of a conference resolution on civil liberties (40 in Papers I4) to praising the determination of imprisoned c.o.s. But even speakers less circumspect in their choice of language escaped prosecution.

\section{RUSSELL RESTRICTED-BY ADMINISTRATIVE ORDER}

This apparent reluctance to enforce DORA's censorship powers through the courts was consistent with the policy of judicial (as opposed to administrative) restraint favoured at the Home Office. Even Cave, Samuel's more hardline successor, warned his Cabinet colleagues that "prosecutions for seditious speeches are seldom advisable." ${ }^{35}$ Although Russell was spared another DORA prosecution for twenty months, other reprisals quickly followed his June I9I6 conviction: he was barred from travelling to America to teach at Harvard and dismissed from his Trinity College lectureship..$^{36}$ Then, on I September, he was served by the War Office with an order under DORR I4 forbidding him from entering any of Britain's "prohibited areas". These covered almost the entire coastline, military and naval installations, and some centres of war production. Since the restricted zones were out of bounds by default only to enemy alien civilians, Russell

\footnotetext{
34 See White, "Soviets in Britain: the Leeds Convention of I9I7" (I974), pp. I86-9.

35 СAB 24/4/GI73, I3 Nov. 1917 ("Pacifist Propaganda"), National Archives, UK.

${ }^{36}$ See Papers 13: lx-lxiv and Delany, "Russell's Dismissal from Trinity" (I986).
} 
was indignant that his loyalty was being thus impugned. He complained immediately to Ottoline that the War Office was invoking "a power conferred on them for dealing with spies, and they choose to suppose that I want to give military information to the Germans. It makes my blood boil" (I Sept. 1916; Papers 13: 453). Herbert Samuel was initially uncomfortable with the sanction, noting internally that there was "no suspicion, of course, that he [Russell] is an enemy agent". The Home Office only wanted a one-off order to stop Russell from travelling to meet a group of c.o.s in Haverhill, Suffolk. The idea for a blanket ban was the brainchild of the fledgling internal security agency MI5, whose chief, Colonel Vernon Kell, considered it a useful safeguard against Russell "airing his vicious tenets amongst dockers, miners and transport workers". ${ }^{37}$

Neither of Russell's convictions under DORR 27 elicited quite the unanimity of outrage as the curtailment of his freedom of movement. DORR I4 was another contentious tool of emergency executive discretion which, like DORR 5I, sidestepped ordinary judicial processes. Although a somewhat novel imposition, Russell's exclusion from Britain's prohibited areas was not the first such application of DORR I4 for blatantly political ends. At the height of the craft unions' struggle against the "dilution" of skilled labour in Glasgow in April I916, six members of the militant Clyde Workers' Committee had been deported from that city under the same DORR. ${ }^{38}$ Russell had little chance of overturning the order in court because in May I9I6 a loose construction of DORR I4-based on "honest", as opposed to "reasonable", grounds for suspicion-had been affirmed by Lord Chief Justice Reading in Rex v. Denison. ${ }^{39}$ The Law fournal nevertheless complained that even this executive-friendly ruling could not be stretched "to the length which appears to have been assumed in Mr. Russell's case"..$^{\circ}$

Russell was more hopeful, he wrote to Ottoline, about drumming

${ }^{37}$ Samuel (minute), I Sept. I916; Kell to Blackwell, 3 Sept. I916, Ho 45/1 IoI2/ 314670, National Archives, UK. Samuel's biographer observes that the prohibition was authorized in the Home Secretary's absence by his senior officials, Troup and Blackwell, and suggests that he might have cancelled the order on returning had it not already been served (see WaSSERSTEIN, Herbert Samuel [1992], p. I93).

$3^{8}$ See McLean, The Legend of Red Clydeside (1983), pp. 8I-3.

39 See "Law Report, May 22", The Times, 23 May I916, p. 3. The unsuccessful applicant was a German-born hairdresser.

40 "Restricted Residence", 9 Sept. I917, p. 447. 
up "a great agitation to have the order rescinded" (9 Sept. 1916; Papers 13: 472). Such efforts both inside and outside Parliament proved fruitless, however, as the British Government dug in its heels. Despite his earlier misgivings, Samuel now stoutly defended official policy from the fierce attacks of Russell's supporters in the House of Commons. ${ }^{4 \mathrm{I}}$ The Home Secretary was ably abetted by David Lloyd George, who justified the summary treatment of Russell on the grounds that "prevention is better than prosecution." The next day (I9 October I9I6), Ottoline's husband, Philip, Liberal MP for Burnley, threw this legally dubious dictum back at Russell's wartime nemesis:

The right hon. Gentleman the Secretary for War said that it was easier to prevent than to prosecute.... Of course in a certain way it is much easier to govern by administrative order than by process of law. It is much easier to say: "Oh, no, we shall give an order to stop it beforehand rather than prosecute afterwards, and after treasonable utterances." It is easier, but is it the way to allow fair freedom of opinion in this country? Is it carrying out the undertaking which the Government gave when the Defence of the Realm Act was passed that they would not do anything to suppress fair political opinion? ${ }^{42}$

Such parliamentary protests ${ }^{43}$ may have been rhetorically powerful, but they did not ease Russell's plight. The ban actually remained in effect until July I9I 8 when, in a gesture singularly lacking in magnanimity, it would be withdrawn when Russell's movements were far more seriously constrained by his confinement to Brixton Prison. As

${ }^{4}$ I See, for example, "Consolidated Fund (No. 5) Bill", Parliamentary Debates (Commons), 5th ser., 86 (19 Oct. 1916): 864-82 (at 878-82).Yet Samuel was never at ease in his role as apologist for DORA. Some months after leaving Cabinet when the Lloyd George Coalition was formed in December 1916, the Liberal ex-Home Secretary longed for that moment when "the Defence of the Realm Acts, with all their prolific offspring of Orders in Council and Regulations, will disappear into the limbo of forgotten things to the profound relief of a long-suffering nation" (The War and Liberty and an Address on Reconstruction [1917], pp. 58-9). When unburdened by office Samuel also lobbied his successor to soften a new and disputed DORR, 27C: see Samuel to Cave, 27 Nov. I9I8 (copy), CAB 24/34/GT2820 (“Censorship of Leaflets"), National Archives UK, and pp. I2 I-2 below for the wider controversy.

42 "Mr. Bertrand Russell's Lectures", Parliamentary Debates (Commons), 5th ser., 86 (I8 Oct. I9I6): 538-40 (at 539); "Defence of the Realm Act (Mr. Bertrand Russell's Lectures)", ibid. (19 Oct. I916): 825-39 (at 830).

43 C. P. Trevelyan also spoke up for Russell: "Mr. Bertrand Russell", Parliamentary Debates (Commons), 5th ser., 88 (28 Nov. 1916): 288-300 (at 288-92). 
a great lover of the sea, ${ }^{44}$ Russell personally chafed under the restrictions placed on him by DORR I4. On a professional level, he was soon prevented from delivering his autumn I9I6 lecture series, "The World as It Can Be Made", in three of the five cities in which he was booked to speak..$^{45}$ On I6 October, however, partially confounding Colonel Kell's desired silencing of Russell, the opening lecture (entitled "Political Ideals") was read in absentia to a large labour gathering in Glasgow by Robert Smillie, President of the Miners' Federation.

Shortly after the prohibited areas ban was imposed, the War Office offered to lift it so long as Russell promised "not to continue a propaganda which, if successful, would in their opinion militate to some extent against the effective prosecution of the war." ${ }^{46}$ In a published commentary on this overture from the War Office, Russell raised some practical objections to such a compact, "First and foremost", however, he refused to make it on principle:

... I cannot acknowledge the right of the War Office to prevent me from expressing my opinions on political subjects. If I say anything which they think prejudicial to the conduct of the war, they can imprison me under the Defence of the Realm Act, but that is a proceeding to which I am not a party, and for which I have no responsibility. If, however, I enter into a bargain by which I secure certain advantages in return for a promise, I am precluded from further protest against their tyranny. Now it is

44 "I can't tell you how I long for the SEA", he wrote Ottoline from prison on 2I August I9I8, after learning that the prohibited areas order had finally been lifted (CLBR, russell-letters.mcmaster.ca/brixton-letter-75). On I2 December I9I6 Russell had visited the Sussex coast to attend the court-martial of Clifford Allen at Newhaven Fort. Somewhat surprisingly, he had been allowed to do so (subject to strict conditions) by the garrison commander, whose permission was required by DORR 29B (irrespective of the application to Russell of DORR I4) since the fort was located in a "special military area" and therefore even more off-limits than a prohibited area. A leaf in Russell's Defence of the Realm Permit Book (see Papers I3: Plate viII, and www.humanities.mcmaster.ca/ bertrand/misc.html) shows that the necessary authorization was refused but that "special arrangements" were made for him to observe his friend's military trial. The same file (RA2 7I2) also contains a letter from the garrison commander instructing Russell to proceed directly from the station to the courtmartial, and the pass (typed on a small slip of paper) with which he must have travelled, stipulating that he "be attended by an escort during his time in Newhaven".

45 Russell was banned from Glasgow, Edinburgh and Newcastle but allowed to speak in Birmingham and Manchester. The lectures were later published in the United States as Political Ideals (I917; Pt. vi in Papers I4).

${ }^{46}$ Sir Reginald Brade to Russell, II Sept. I916 (copy), Ho 45/IIoI2/314670, National Archives, UK. 
just as imperative a duty to me to fight against tyranny at home as it is to others to fight against the Germans abroad. I will not, on any consideration, surrender one particle of spiritual liberty. ${ }^{47}$

Indeed, Russell consistently baulked at such bargaining, even when (in the spring of 1918) he was facing imprisonment after a second conviction on DORA charges and the equally disturbing possibility of being conscripted after his release. ${ }^{48}$ "I will not give an undertaking to avoid propaganda", he told his friend Gilbert Murray-despite having resolved several months previously to return to philosophy. "Although I see no present likelihood of altering this intention", he continued, "I will not be under any honourable obligation not to alter it" (2 April I9I8, RA Rec. Acq. 7Ie). The ethical distinction he drew was "between an intention and a promise", he explained further to Murray two days later, and he would "give no promise, express or implied." ${ }^{9}$

Ironically, a unilateral concession that Russell could have accepted without qualm seemed imminent just before he fell foul of DORA once again. In December 1917 Frank Russell discreetly informed General George Cockerill (Director of Special Intelligence at the War Office and an official with whom Russell had personally dealt [see 69 in $\mathrm{Pa}$ pers 13$]$ ) that his brother was intending to pull back from organized peace work and that, therefore, the prohibited areas ban might be dispensed with safely. ${ }^{50}$ Russell's acting chairmanship of the NCF and his editorial role at The Tribunal were both about to end. By I 8 December

47 "Bertrand Russell and the War Office" (1916; 70 in Papers 13: 46I).

${ }^{4}$ On Russell's second trial and conviction under DORR 27, see pp. II6-I8 below. In April 1918, the Military Service (No. 2) Act increased the upper-age limit of British conscripts from 45 to 50 . Since teachers older than 45 were exempt from the provisions of the amended legislation, Russell, in prison, grew increasingly preoccupied with obtaining academic employment of some kind as insurance against being called up after his release. Nevertheless, "the unnerving prospect of a military call-up hung over the 46-year-old BR throughout his imprisonment" (CLBR, russell-letters.mc master.ca/brixton-letter-6).

49 SLBR 2: I43. Murray and Russell disagreed vehemently over the merits of the war, although less sharply in 1918 than in 1915, when they published rival accounts of Britain's pre-war diplomacy (see 37 in Papers 13). Despite these recent political differences, Murray assiduously lobbied professional philosophers to petition the Home Secretary for Russell to be spared the harsh conditions and strict discipline to which second-division prisoners were subject. Towards the end of Russell's sentence Murray also spearheaded the so-called "fellowship plan" (see n. 48 above, and $C L B R$, russell-letters.mcmaster.ca/general-annotation/59).

${ }^{50}$ See Papers I4: xlix, 39I. 
he had already presented the lectures from which his Introduction to Mathematical Philosophy (1919) would emerge in Brixton Prison, and, in a further demonstration of professional intent, he was scheduled to deliver another series, "The Philosophy of Logical Atomism", in the new year. The War Office was amenable to rescinding the DORR I4 order, and both the Home and Foreign Secretaries concurred by midJanuary 1918. ${ }^{\text {I }}$ But any chance of Russell obtaining this concession quickly disappeared, for the article that triggered his second DORA prosecution, "The German Peace Offer" (92 in Papers 14), was already in print. After it came to the notice of the Home Office, Sir Ernley Blackwell minuted ominously that he had "called General Cockerill's attention to Russell's article in the Tribunal of 3 Jan." ${ }^{2}$

\section{THE ROAD TO BRIXTON PRISON}

This fateful piece of political commentary contained the ill-judged sniping at the strike-breaking proclivities of the American military for which Russell was charged early in February I9I8, under DORR 27, with prejudicing "His Majesty's relations with foreign powers". Ironically, Russell's journalistic involvement with the NCF weekly was supposed to have ceased with the appearance of his previous article on 27 December 1917. But he agreed to contribute two further pieces while one of The Tribunal's new co-editors, Lydia Smith, recovered from illness (Papers 14: 389). The allegedly prejudicial aside was quite tangential to the article as a whole, which unenthusiastically predicted the spread of revolutionary violence across Europe should peace feelers from the enemy camp - treated by Russell as sincere-continue to be rebuffed by Allied statesmen. ${ }^{53}$

After Russell was convicted at Bow St. court on 9 February, Gilbert Murray was indignant at this "further persecution" of his friend. Having read "The German Peace Offer", Murray could not "understand how any honest magistrate can have persuaded himself that there was anything in it to deserve punishment" (IO Feb. I9I8, RA

${ }^{51}$ Copies of this correspondence are in HO 45/IIOI2/314670, National Archives, UK.

${ }^{52}$ I7 Jan. 1918, ibid.

53 For Russell's commentary on "The German Peace Offer", see "Draft of Defence" (95 in Papers 14), prepared for his appeal, shortly before the pitiless terms imposed on the Bolsheviks by the Treaty of Brest-Litovsk (3 March 1918) led Russell to reappraise both German diplomacy and his own exertions for peace (ibid., 388-9). 
Rec. Acq. 7If). Whether in good faith or not, Sir John Dickinson had found Russell guilty of what he called a "very despicable" offence and imprisoned him for six months in the second division - the maximum term at his disposal. ${ }^{54}$ The offence was so despicable, in fact, that Russell had already committed it four months previously in a satirical piece for The Tribunal that drew no official ire-despite imagining a British war leader thinking that if organized labour was flexing its political muscle at the war's end, "we may hope to have an American garrison in the country ready to shoot down strikers." 55

According to the Morning Post's earlier hostile characterization, Russell was "an extremely troublesome person" ${ }^{56}$ and was regarded as such by government officials as well as this Conservative voice of the British officer class. But if Russell's generally vexatious conduct was the underlying cause of his prosecution in 1918, why had he remained at liberty (albeit subject to the constraints of DORR I4) until the final months of the war? A close legal reading of his writings from The Tribunal and other publications might well have uncovered infractions of DORA just as likely to result in a conviction as that for which he was summonsed early in I9I8.

Unfortunately, no completely satisfactory explanation of Russell's second DORA trial has emerged in the two decades since the case was last considered in depth, in Collected Papers I4. The Home Office file on Russell's wartime pacifism sheds light on his first DORR 27 case, some suspected breaches of DORA that were not acted upon, as well as the unsuccessful appeal of the I9I8 conviction and his and Frank Russell's dealings with the Brixton authorities. But there are no departmental minutes or legal opinions on the merits or pitfalls of charging Russell in connection with "The German Peace Offer". ${ }^{57}$ Since the publisher of The Tribunal, Joan Beauchamp, was tried on the same charge as Russell, a Home Office file on the NCF may have held the missing information. But these records were destroyed, as reported

54 See "Mr. Bertrand Russell Sentenced", The Times, II Feb. I9I8, p. 2.

55 "Imperialist Anxieties" (1917; 65 in Papers 14: 298).

${ }^{56}$ See n. 3I above.

57 See Hо 45/IIOI2/314670. No files on Russell have been released under the stringent 75- or 100-year rules, to which certain records of the intelligence and security services are subject. But the apparent lack of anything newly accessible in the UK's National Archives that can easily be associated with Russell does not preclude the dispersal in other files of some such relevant documentation. 
more than twenty years ago by the editors of Collected Papers I4, who also surmised that that "this weekly, rather than Russell, was intended as the primary victim of the crackdown." ${ }^{8}$

Referring to his proposed cessation of peace work (of which the War Office had been made aware by Frank), Russell himself was convinced that "the authorities realized that if they wished to punish me they must act at once, as I should not be committing any further crimes." 59 Eighteen months previously, a defiant and hopeful Russell had more or less welcomed his DORA prosecution. But he had wearied of his administrative role inside the NCF and was depressed at the apparent futility of his political campaigning. By early I9I 8 he was unwilling "to martyr himself for a cause in which there was no longer any hope of success" (Papers I4: 385).

It is conceivable that the legal action against Russell was taken in a fit of pique over his apparent failure to abide by intentions communicated to the War Office by his brother. On I4 March I9I8 Frank Russell complained to General Cockerill about his brother's "vindictive" treatment. But the Director of Special Intelligence insisted that the decision to prosecute had rested with the DPP alone and that he, Mathews, was unaware of Russell's impending departure from the political fray. "No proof of vindictiveness can, therefore, be drawn from the facts", Cockerill replied three days later. Notwithstanding the General's explanation, "the belief that Russell had been singled out for persecution persisted in NCF memory as late as the I970s." 60

Whatever political and legal considerations influenced the decision to prosecute Russell again, this course was rather at odds with the disinclination to proceed in such DORA cases. ${ }^{61}$ The authorities

$5^{8}$ P. 390. On the persistent harassment of The Tribunal and its eventual recourse to clandestine publication, see KENNEDy, pp. 247-5I.

59 To Gilbert Murray, I5 Feb. I918; Auto. 2: 8I.

60 Papers I4: 39I, where the Frank Russell-General Cockerill exchange is also quoted.

${ }^{61}$ In March I9I8 several police chiefs expressed frustration at the reluctance of area Competent Military Authorities (to whom constabularies deferred in such matters) or the DPP to act against local peace campaigners and pressed the Home Office (unsuccessfully) for leeway to initiate proceedings themselves (HO 45/1 1007/271672/228 ["Extract from Minutes of Conference of Chief Constables for District I Held on 6th March 1918”], National Archives, UK). Glamorgan's pugnacious Chief Constable was especially frustrated; he considered that disloyalty was rife in South Wales and needed to be deterred by prosecuting the worst offenders. This had occurred more routinely until the end of 1916 , before when only a handful of reported infractions (including Russell's Cardiff speech) had not been prosecuted. HO 45/10743/ 
seemed especially reluctant to indict prominent peace advocates, such as Russell, Trevelyan, E. D. Morel, and Independent Labour Party MP Philip Snowden. In September 1916, for example, the Foreign Office pressed the DPP to act against Morel under DORR 27, after taking particular umbrage at his critique of pre-war Allied diplomacy, Truth and the War (I9I6). Mathews agreed that the UDC leader's work was "of a most objectionable" character and possibly in prejudice of Britain's relations with foreign powers. Yet he advised against laying charges because "in Morel a defendant might be discovered to whom, provided he could secure a larger publicity for his mischievous propaganda, a prosecution might not be unwelcome." ${ }^{62}$ This counsel was similar to that which Mathews had given the Home Office in discouraging legal action over Russell's Cardiff speech.

On I5 December i9i6 Sir Ernley Blackwell of the Home Office minuted that if "the [peace] movement remains small, prosecution would do more harm than good. If the movement grows to considerable dimensions prosecutions will not repress it." ${ }^{63}$ This assessment was increasingly accepted at the highest levels of government, where a shift in emphasis from proscription to public persuasion occurred over the next year, with the creation in June I9I7 of the quasiindependent (but Treasury-funded) National War Aims Committee the most notable institutional change. ${ }^{64}$ Inside the War Cabinet, the social-imperialist Lord Milner displayed particular enthusiasm for

$263275 / 284$ has the particulars of all DORR 27 cases submitted by the Glamorgan county constabulary from the start of the war until November 1917. See also HopKIN, "Domestic Censorship in the First World War" (I970), pp. I66-7.

${ }^{62}$ See Lord Newton (assistant under-secretary) to Mathews, 20 Sept. I9I6, Fo 395/15/ 169424, National Archives, UK, and Mathews to Foreign Office, Io Oct. I916, FO $37 \mathrm{I} / 2828 / 3255 / 202398$. In a note filed with the latter communication, Newton complained that the "Public Prosecutor will always find some excuse for not acting."

${ }_{63}$ HO 45/10786/297549/50 ("Publications: Labour Leader and Independent Labour Party Press"), National Archives, UK.

${ }^{64}$ See Millman, Managing Domestic Dissent in First World War Britain (2000), ch. 9. There is a vast literature on the subject of war propaganda generally, in which this author's detailed study stands out for its provocative analysis of the Lloyd George Coalition's propaganda machine in terms of a multifaceted counter-revolutionary strategy, proto-fascist in character, which was crafted in the final year of the war as insurance against civil strife but never fully implemented. For an excellent and still useful overview, covering the censorship of war news and the manipulation of foreign as well as domestic opinion, see SANDERS AND TAYLOR, British Propaganda during the First World War, I9I4-I9I8 (1982). 
buttressing the pro-war sentiments of British workers. ${ }^{65}$

Yet these more purposeful approaches to propaganda were still fortified by DORA. In the last year of the war more than ever, the authorities favoured constraining dissent by administrative as opposed to judicial means. Sir George Cave, the Conservative politician and lawyer who succeeded Samuel at the Home Office in December I9I6, showed far less scruple than his predecessor about the seizure and destruction of anti-war literature under DORR 5I. In October I9I7 he defended his less measured application of this power after suppressing an issue of Sylvia Pankhurst's Workers' Dreadnought: "If we do not seize the paper until after a prosecution," he told MPs, "it is too late, because the paper is already published." ${ }^{66}$ In a short statement also announcing the appointment of a Home Office Advisory Committee to consider what materials confiscated under DORR 5I should be destroyed, Cave informed the House of Commons early in I9I8 that twenty-four such search and seizure raids had been carried out by police from September to November of the previous year. ${ }^{67}$

Cave's preference for the containment of dissent extra-judicially was manifest in his department's leading role in the promulgation on I6 November I9I7 of DORR 27C, which imposed a hitherto unheardof preventive censorship. In "The New Dictatorship of Opinion" (82 in Papers I4), Russell castigated this novel edict, which had been introduced (like all DORRs) without parliamentary scrutiny and required any pamphlet, leaflet or circular about the war or future peace terms to be approved by the Official Press Bureau. (By the same Order

65 See StubBs, "Lord Milner and Patriotic Labour, I9I4-I9I8" (I972), and Millman, Managing Domestic Dissent, pp. I I2-I6.

66 “Workers' Dreadnought (Seizure)", Parliamentary Debates (Commons), 5th ser., 98 (29 Oct. I9I7): I, I78-9 (at I, I79). During Cave's wartime tenure of the Home Office several items were added to the "Hostile Leaflets" circular in this peremptory fashion, including soldier-poet Siegfried Sassoon's famous anti-war statement, partly authored by Russell and made public initially in a Commons speech by a sympathetic Liberal MP. A "Hostile Leaflets Consolidation List", issued by the Home Office on I July I9I8, contained only one title by Russell: Two Years' Hard Labour, the embargo on Rex v. Bertrand Russell presumably having been lifted (see HO I58/20, National Archives, UK). But the prohibited literature did include two issues of The Tribunal: those of I5 November I9I7, which featured Russell's scathing attack on a mooted token concession to imprisoned c.O.s (8I in Papers I4), and of I4 February I9I8, containing front-page coverage of his Bow St. trial five days previously.

67 "Police Raids", Parliamentary Debates (Commons), 5th ser., IOI (I7 Jan. I9I8): 4823. See also n. 24 above. 
in Council, DORR 5I was amended as well, to allow for the seizure and destruction of material printed or distributed in contravention of DORR 27C.) Returning to the attack in The Tribunal, Russell forecast that, "In consequence of this new Regulation, the Government can (and doubtless will) suppress all expression of opinion in any way critical either of its war aims or of the conduct of the war...." 68

Russell was not mistaken on the latter score, since his civil libertarian's disquiet was echoed in some pro-war circles, where it was feared that the application of DORR 27C to the patriotic press might foreclose any questioning of British domestic policy or Allied strategy. On this occasion, the peace movement's interests intersected with those of a more powerful constituency, and, as a result, an amending Order in Council was issued a few weeks later (on ro December). Russell was gratified, he told his NCF colleague Catherine Marshall, "by the prospect of 27C being practically withdrawn" (29 Nov. I9I7; Papers I4: 343). Yet even the amended DORR remained a useful weapon in the government's anti-dissenting arsenal. Although the prior approval provision of $27 \mathrm{C}$ was removed, the printers of leaflets were still required to submit copy at least 72 hours before publishing. The authorities were therefore better able than previously to monitor the output of pacifist literature and already equipped with DORR 5I to suppress allegedly objectionable material. ${ }^{69}$

This further extension of DORA was bound up with attempts, both official and unofficial, to discredit and marginalize anti-war dissent by exposing the enemy influences behind it-about which Russell wrote witheringly in The Tribunal. ${ }^{70}$ The peace movement was placed on the defensive not only by DORR 27C but by a series of coordinated Metropolitan Police raids targeting different individuals and groups. ${ }^{71} \mathrm{Al}-$ though the ensuing inquiries yielded no evidence of British pacifists in the pay of German agents, the associated political hysteria was helpful in constricting dissenting propaganda. The ultimately forlorn quest

68 "Boloism in Power" (1917; 84 in Papers I4: 366).

${ }^{69}$ Systematic scrutiny of dissenting propaganda was but one feature of the heightened political surveillance that operated under the Lloyd George Coalition after December 19 I6 (see Millman, Managing Domestic Dissent, pp. 178-9).

${ }^{70}$ See n. 68 above and "Who Is the British Bolo?" (I917; 83 in Papers 14).

${ }^{71}$ See Papers I4: xlv and, for an account by the lead investigating officer, the memoirs of Basil Thomson (Assistant Commissioner of the Metropolitan Police and head of its Criminal Investigation Department): The Scene Changes (1937), pp. 394-5. 
for a "British Bolo" reflected official concerns about deteriorating civilian morale and burgeoning support for a negotiated peace. ${ }^{72}$ The endorsement of this keynote dissenting demand by a Conservative ex-Foreign Secretary, Lord Lansdowne, added much-needed respectability to the campaign to moderate British war aims - as well as speaking to establishment doubts that the war was winnable. ${ }^{73}$ Allied strategy was certainly faltering late in 1917. On the Western Front, the costly Passchendaele offensive petered out just as Italy's continued participation in the war was placed in jeopardy by the disastrous defeat of its Second Army at Caporetto in the Austro-Italian theatre. To the east, the second Russian Revolution installed a Bolshevik regime unequivocally committed to peace and whose immediate publication of Tsarist secret treaties confirmed the suspicions of Russell and other dissenters about grasping Allied war aims (see Papers I4: 350 ). ${ }^{74}$

At home, the obvious strains of the war on the civilian populationhigh prices and food shortages in particular-were feared as solvents of an already weakened patriotic resolve. An incipient domestic crisis deepened in the new year with the launch of a fresh "comb-out" of

72 "Boloism" became a byword for disloyalty and defeatism after French spy PaulMarie Bolo (a.k.a. Bolo Pasha) was arrested on suspicion of treason in September 1917- a charge on which he was convicted by court-martial the following February and executed two months later. One of Russell's points, however, was that the revelations about Bolo had not discredited France's peace party, but rather, a section of the nation's jingo press, whose promotion of territorial aggrandizement had been funded by Bolo, he argued, "as a means of combating the peace party in Germany" ("Boloism in Power"; Papers 14: 366). The search for British "enemies within" also had a populist dimension, which was stoked by right-wing newspapers and tacitly condoned or even abetted by the authorities. The disruption of anti-war meetings was a favourite ploy, and Russell witnessed such organized rowdyism at first hand when in July I9I7 a follow-up meeting to the Leeds Convention (see p. III above), at the Brotherhood Church, Southgate, was violently broken up (see Auto. 2: 3I-2). Dissent clearly had a "hyper-patriotic" face, grounded in the resentments of a warweary middle class, as well as its more familiar pacifist aspect. Both tendencies could be vexing to the British Government, the former when its frustrations were directed not at the peace movement, but at the supposed weakness and incompetence of the nation's political leadership (see GREGORY, The Last Great War [2008], p. 233ff., for several different manifestations of patriotic protest).

73 On how this loss of confidence influenced British strategic thinking, see Millman, Pessimism and British War Policy (2001). On the significance of the "Lansdowne Letter" to anti-war dissent, see, for example, CEADEL, Semi-Detached Idealists: the British Peace Movement and International Relations (2000), pp. $23 \mathrm{I}-3$.

${ }^{74}$ For an international perspective, see Stevenson, 1917: War, Peace, and Revolution (2017), chs. 7-9. 
skilled workers for the army, bitterly resented and resisted by their craft unions. ${ }^{75}$ An intermingling of strategic and political considerations finally persuaded Lloyd George to elaborate British war aims in a clever speech to trade union leaders delivered two days after the appearance of "The German Peace Offer". The Prime Minister borrowed from the Labour Party's reformulated foreign-policy plan (of which Russell approved) and anticipated the liberal spirit of President Wilson's "Fourteen Points", but he did not dispense with Germany's unconditional surrender as his overriding objective. ${ }^{76}$

The decision to charge Russell early in I9I 8 was made against this tumultuous backdrop. Although it is unlikely that any overarching political concerns were voiced in missing government documents, the edginess in official circles at a critical juncture of the war is worth noting in relation to Russell's second DORA trial. These anxieties may have had some bearing on the abandonment of a previously exhibited restraint in the prosecution of anti-war speakers and writers. Russell was undoubtedly a bothersome irritant to the authorities (as indeed was $\mathrm{Morel}^{77}$ ), not to mention the patriotic press and public. But it was a more dangerous confluence of peace sentiment with working-class unrest that placed British officialdom on a higher state of alert early in I9I8, as the editors of Collected Papers I4 argue (pp. 385-6). Brock

75 On the grievances of working-class consumers and the industrial unrest, see GREGORY, pp. 194-208, 213-16.

${ }^{76}$ Russell voiced scepticism about the Prime Minister's speech in his final article for The Tribunal, "The Bolsheviks and Mr. Lloyd George" (I9I8; 93 in Papers I4). In his penultimate contribution (i.e., "The German Peace Offer") he praised Labour's "Memorandum on War Aims" as "on the whole very sane" (Papers I4: 399).

77 After proceedings against Morel were again ruled out in February I9I7 (see Fo 395/ I40/25424/33266, National Archives, UK), he was finally charged that September, under DORR 24B, with attempting to convey without a permit one of his pamphlets to a French pacifist in Switzerland. An additional charge of incitement was brought against Morel under DORR 48, because he had allegedly approached a third party (Ethel Sedgwick, a niece of the Foreign Secretary, Arthur Balfour) to transport the material in question. The advantage of these indictments to the Crown was that Morel could not (as in a DORR 27 case) place British foreign policy under potentially embarrassing courtroom scrutiny - even though his published writings were "patently the cause of the Government's determination to prosecute him" (Cline, E. D. Morel, I873-I924 [I980], p. III). Morel was convicted and sentenced to six months in the second division of Pentonville Prison. His emergence from there in such physically broken condition persuaded a badly shaken Russell (whose conviction was then under appeal) that he must do everything possible to ensure that his sentence, if upheld, be served in the far less cruel and punitive confinement of the British penal system's first division (see Papers I4: 393). 
Millman emphasizes the extent of such fears and how the wartime state responded vigorously to neutralize a possible revolutionary defeatist challenge. ${ }^{78}$ Its preventive measures ranged far beyond the incarceration of a troublesome "Pacifist at Large". Even if the political situation was not quite so parlous, working-class discontent was very real and peaked early in 1918 when, according to Adrian Gregory, "prospects never seemed bleaker" on either the home or battle fronts. ${ }^{79}$ The same historian, however, characterizes the official response as "domestic appeasement", rather than a prelude to counterrevolution. The British Government's position may have been shored up by its intensified propaganda efforts, but "it was the background of food subsidies, war bonuses and a cautious approach to the manpower problem that defused tension." 80

When Russell entered Brixton Prison on I May, the outcome of the war was still uncertain. In two spring offensives Germany had come close to breaking through on the Western Front. A third such assault made some progress late in May, but left advancing troops badly exposed when their forward movement was stalled-with American forces a crucial factor for the first time in these defensive operations. Writing to an NCF associate from his prison cell on 17 June, Russell gloomily predicted that the military stalemate would last "about another ten years". ${ }^{81}$ But his forecasts grew more sanguine after AustroHungarian forces were routed on the Piave in the Italian theatre and as Germany's last offensive gambit was contained and then repulsed by a successful counter-attack in the second Battle of the Marne. ${ }^{82}$ Ironically, the political fears that may have landed Russell in prison were gradually eased when he was behind bars. The spectre of continued strategic impasse - or, worse, battlefield reverses—spilling over the English Channel into political revolt faded further as Russell's sentence neared its end in the late summer, and a rapid succession of Allied victories fatally weakened German resistance.

${ }^{78}$ Managing Domestic Dissent, chs. IO and II.

79 The Last Great War, p. 213.

${ }^{80}$ Ibid., p. 204.

${ }^{81} C L B R$, russell-letters.mcmaster.ca/brixton-letter-20 (to Gladys Rinder).

82 "One begins to see a possible end to the war", he wrote Ottoline on I4 August, "the end of next year, I should guess" (CLBR, russell-letters.mcmaster.ca/brixton-letter70). On the increasingly fluid military situation across multiple fronts, see STEvenson, With Our Backs to the Wall: Victory and Defeat in 1918 (20II), chs. I-2. 


\section{CONCLUSION}

With a deliberately exaggerated flourish the Liberal Daily News of 2 December 19I4 had expressed alarm at the new Defence of the Realm Act. ${ }^{83}$ This consolidating measure conferred powers on the state "ample enough to turn this country into a Socialist Mecca or to start an unending stream of heads rolling into the mud of Tower Hill; and between these two extremes there is space for an infinity of lesser plagues and vexations." 84 The many "lesser plagues and vexations" for which DORA would be responsible over the next four years (including such curious rules as one against dog shows: DORR 9DD) lie far beyond the remit of this paper. The same applies to the proliferation of statist economic controls under DORA's statutory umbrella. Russell's head did not roll "into the mud of Tower Hill", but during an intense phase of political engagement he was fined, restricted in his freedom of movement, and finally imprisoned by DORA's sanction.

These reprisals touch on the broader question of how profoundly this emergency legislation affected civil liberties in wartime Britain. Given the latitude afforded by DORA, Russell and the peace movement might have been more ruthlessly suppressed-like their counterparts in other combatant nations. Yet a degree of official caution has been noted in the administration of DORA, which effectively authorized any action judged expedient for the defence of the realm. But such moderation was shaped more by instrumental considerations than principled reservations about enforcing Britain's emergency legal code and applied more to the prosecution of DORA cases than to the use of its powers extra-judicially. Moreover, the containment of anti-war dissent involved much else besides the selective application of DORA. For the bulk of a patriotic public, DORA was a sometimes irritating but not disproportionate legal response to the crisis of war. The critics of this "other DORA" (Russell among them) were usually an isolated minority. Yet if he and those who protested his maltreatment had been less vigilant guardians of liberties under stress, Russell, for one, might have been ensnared more often and easily by "the Hydra-headed monster which ... grew out of the phrase 'defence of the realm'." 85

\footnotetext{
${ }^{83}$ I.e., the Defence of the Realm Consolidation Act (see n. 3 above).

84 "The World We Live In", p. 4.

${ }^{85}$ Allen, Law in the Making (I927), p. 462.
} 
APPENDIX: DORRS INVOKED AGAINST RUSSELL

*Source: Defence of the Realm Manual, 4th ed., rev. to 3I May I9I7. (Manuals of Emergency Legislation.) Edited by Alexander Pulling. London: HMso, I9I7. Except for DORR 5I, ibid., 6th ed., rev. to 3I Aug. I9I8 (I9I8).

\begin{tabular}{|c|c|c|c|}
\hline $\begin{array}{l}\text { DORR } \\
\text { No. }\end{array}$ & $\begin{array}{l}\text { Official } \\
\text { Description* }\end{array}$ & Selected Text ${ }^{\star}$ & $\begin{array}{l}\text { Application to } \\
\text { Russell }\end{array}$ \\
\hline $\begin{array}{l}\text { I4 } \\
\text { (Issued by } \\
\text { Order in } \\
\text { Council, 28 } \\
\text { Nov. 19I4) }\end{array}$ & $\begin{array}{l}\text { Power to } \\
\text { remove sus- } \\
\text { pects from } \\
\text { specified } \\
\text { areas. }\end{array}$ & $\begin{array}{l}\text { [As amended to } 23 \text { March } \\
\text { I915] Where a person is sus- } \\
\text { pected of acting, or of having } \\
\text { acted, or of being about to act } \\
\text { in a manner prejudicial to the } \\
\text { public safety or the defence of } \\
\text { the Realm and it appears to the } \\
\text { competent naval or military } \\
\text { authority that it is desirable } \\
\text { that such person should be } \\
\text { prohibited from residing in or } \\
\text { entering any locality, the com- } \\
\text { petent naval or military author- } \\
\text { ity may by order prohibit him } \\
\text { from residing in or entering } \\
\text { any area or areas which may be } \\
\text { specified in the order... }\end{array}$ & $\begin{array}{l}\text { I Sept. I9I6- } \\
\text { II fuly I9I8: } \\
\text { Barred from } \\
\text { entering all } \\
\text { prohibited } \\
\text { areas scheduled } \\
\text { to the Aliens } \\
\text { Restriction Act. }\end{array}$ \\
\hline $\begin{array}{l}\mathbf{2 4} \\
\text { (Order in } \\
\text { Council, } 28 \\
\text { Nov. 19I4) }\end{array}$ & $\begin{array}{l}\text { Prohibition } \\
\text { on non-postal } \\
\text { communica- } \\
\text { tions to or } \\
\text { from United } \\
\text { Kingdom. }\end{array}$ & $\begin{array}{l}\text { [As amended to } 23 \text { March } \\
\text { I9I5] No person shall without } \\
\text { lawful authority transmit (oth- } \\
\text { erwise than through the post) } \\
\text { or convey, to or from the } \\
\text { United Kingdom, or receive or } \\
\text { have in his possession for such } \\
\text { transmission or conveyance, } \\
\text { any letter or any written } \\
\text { message for any other } \\
\text { person.... }\end{array}$ & $\begin{array}{l}\text { fan. I9I7: } \\
\text { Prosecution for } \\
\text { covert trans- } \\
\text { mission to Us } \\
\text { of open letter } \\
\text { to President } \\
\text { Wilson ( } 2 \text { in } \\
\text { Papers I4) con- } \\
\text { templated, but } \\
\text { no legal action } \\
\text { taken. }\end{array}$ \\
\hline $\begin{array}{l}\mathbf{2 7} \\
\text { (Order in } \\
\text { Council, } 28 \\
\text { Nov. 1914) }\end{array}$ & $\begin{array}{l}\text { Prohibition } \\
\text { on spreading } \\
\text { of false or } \\
\text { prejudicial } \\
\text { reports and } \\
\text { against preju- } \\
\text { dicial perfor- } \\
\text { mances or } \\
\text { exhibitions. }\end{array}$ & $\begin{array}{l}\text { [As amended to } 23 \text { Nov. I9I6] } \\
\text { No person shall by word of } \\
\text { mouth or in writing or in any } \\
\text { newspaper, periodical, book, } \\
\text { circular, or other printed publi- } \\
\text { cation, }(a) \text { spread false reports } \\
\text { or make false statements; or }(b) \\
\text { spread reports or make } \\
\text { statements intended or likely } \\
\text { to cause disaffection to His } \\
\text { Majesty or to interfere with the } \\
\text { success of His Majesty's forces }\end{array}$ & $\begin{array}{l}\text { fune I9I6: } \\
\text { Tried and } \\
\text { convicted for } \\
\text { contravening } \\
\text { clause }(c) \text { in the } \\
\text { Everett leaflet } \\
\text { (49 in Papers } \\
\text { I3). Fined } \\
\text { £IOO. } \\
\text { Aug. I9I6: } \\
\text { Prosecution } \\
\text { over Cardiff }\end{array}$ \\
\hline
\end{tabular}




\begin{tabular}{|c|c|c|c|}
\hline $\begin{array}{l}\text { DORR } \\
\text { No. }\end{array}$ & $\begin{array}{l}\text { Official } \\
\text { Description* }\end{array}$ & Selected Text ${ }^{\star}$ & $\begin{array}{l}\text { Application to } \\
\text { Russell }\end{array}$ \\
\hline & & $\begin{array}{l}\text { or of the forces of any of His } \\
\text { Majesty's Allies by land or sea } \\
\text { or to prejudice His Majesty's } \\
\text { relations with foreign powers; } \\
\text { or }(c) \text { spread reports or make } \\
\text { statements intended or likely } \\
\text { to prejudice the recruiting, } \\
\text { training, discipline, or } \\
\text { administration of any of His } \\
\text { Majesty's forces or the } \\
\text { discipline of any police } \\
\text { force... }\end{array}$ & $\begin{array}{l}\text { speech (6 July } \\
\text { I9I6; } 63 \text { in } \\
\text { Papers I3) con- } \\
\text { templated for } \\
\text { contraventions } \\
\text { of clauses (a) } \\
\text { and/or }(b) \text {, but } \\
\text { no legal action } \\
\text { taken. } \\
\text { Feb. I9I8: } \\
\text { Tried and con- } \\
\text { victed for con- } \\
\text { travening } \\
\text { clause (b) in } \\
\text { The Tribunal } \\
\text { ( } 92 \text { in Papers } \\
\text { I4). Sentenced } \\
\text { to six months } \\
\text { in prison. }\end{array}$ \\
\hline $\begin{array}{l}\mathbf{4 2} \\
\text { (Order in } \\
\text { Council, } 28 \\
\text { Nov. I9I4) }\end{array}$ & $\begin{array}{l}\text { Prohibition } \\
\text { against } \\
\text { causing } \\
\text { mutiny, \&c., } \\
\text { or impeding } \\
\text { production of } \\
\text { war material. }\end{array}$ & $\begin{array}{l}\text { [As amended to I5 Feb. I916] } \\
\text { If any person attempts to cause } \\
\text { mutiny, sedition, or } \\
\text { disaffection among any of His } \\
\text { Majesty's forces or among the } \\
\text { civilian population, or to } \\
\text { impede, delay, or restrict the } \\
\text { production, repair, or transport } \\
\text { of war material, or any other } \\
\text { work necessary for the success- } \\
\text { ful prosecution of the war, he } \\
\text { shall be guilty of an offence } \\
\text { against these regulations. }\end{array}$ & $\begin{array}{l}\text { Aug. I9I7: } \\
\text { Prosecution } \\
\text { over speech to } \\
\text { Leeds Conven- } \\
\text { tion (3 June } \\
\text { I9I7; } 40 \text { in } \mathrm{Pa} \text { - } \\
\text { pers I4) con- } \\
\text { templated, but } \\
\text { no legal action } \\
\text { taken. }\end{array}$ \\
\hline $\begin{array}{l}\text { 5I } \\
\text { (Order in } \\
\text { Council, 28 } \\
\text { Nov. 1914) }\end{array}$ & $\begin{array}{l}\text { Power to } \\
\text { search } \\
\text { premises, \&c. }\end{array}$ & $\begin{array}{l}\text { [As amended to 2I Dec. I9I7] } \\
\text { The competent naval or mili- } \\
\text { tary authority, or any person } \\
\text { duly authorised by him or any } \\
\text { police constable may, if he has } \\
\text { reason to suspect that any } \\
\text { house, building, land, vehicle, } \\
\text { vessel, aircraft, or other prem- } \\
\text { ises or any things therein are } \\
\text { being or have been constructed } \\
\text { used or kept for any purpose or } \\
\text { in any way prejudicial to the } \\
\text { public safety or the defence of } \\
\text { the Realm, or that an offence } \\
\text { against these regulations is }\end{array}$ & $\begin{array}{l}\text { Summer I9I6: } \\
\text { The Everett } \\
\text { leaflet ( } 49 \text { in } \\
\text { Papers } 13 \text { ) and } \\
\text { Rex v. Bertrand } \\
\text { Russell ( } 56 \mathrm{~b} \text { in } \\
\text { Papers } 13 \text { ) } \\
\text { made liable to } \\
\text { seizure and } \\
\text { destruction } \\
\text { after being } \\
\text { placed on the } \\
\text { Home Office } \\
\text { "Hostile Leaf- } \\
\text { lets" circular. }\end{array}$ \\
\hline
\end{tabular}




\begin{tabular}{|c|c|c|c|}
\hline $\begin{array}{l}\text { DORR } \\
\text { No. }\end{array}$ & $\begin{array}{l}\text { Official } \\
\text { Description* }\end{array}$ & Selected Text ${ }^{\star}$ & $\begin{array}{l}\text { Application to } \\
\text { Russell }\end{array}$ \\
\hline & & $\begin{array}{l}\text { being or has been committed } \\
\text { thereon or therein, enter, if } \\
\text { need be by force, the house, } \\
\text { building, land, vehicle, vessel, } \\
\text { aircraft, or other premises at } \\
\text { any time of the day or night, } \\
\text { and examine, search, and } \\
\text { inspect the same or any part } \\
\text { thereof, and may seize any- } \\
\text { thing found therein which he } \\
\text { has reason to suspect is being } \\
\text { used or intended to be used for } \\
\text { any such purpose aforesaid, or } \\
\text { is being kept or used in contra- } \\
\text { vention of these regulations ... } \\
\text { [and] may order anything so } \\
\text { seized to be destroyed or } \\
\text { otherwise disposed of. }\end{array}$ & $\begin{array}{l}\text { Nov. I9I7: } \\
\text { The Tribunal } \\
\text { dated I5 Nov. } \\
\text { (containing 8I } \\
\text { in Papers I4) } \\
\text { added to the } \\
\text { "Hostile Leaf- } \\
\text { lets" circular. }\end{array}$ \\
\hline
\end{tabular}

AuthoR's Note: I would like to thank members of the Bertrand Russell Society who responded to an early version of this paper that was read to their annual meeting at McMaster University in June 20I8. Much of the original research (especially in the UK's National Archives) was carried out for my 1994 PHD thesis, which was supervised by Richard A. Rempel, who also commented helpfully on the proofs. I also acknowledge Russell's anonymous reviewers for their constructive criticisms and the Bertrand Russell Research Centre's student assistants, Jaskaran Basuita and Marley Beach.

\section{WORKS CITED}

Allen, C. K. Law in the Making. Oxford: Clarendon P., I927.

Bone, Andrew G. "Beyond the Rule of Law: Aspects of the Defence of the Realm Acts and Regulations, I9I4-I8". PHD thesis. McMaster U., 1994.

Buckley, Suzann. "The Failure to Resolve the Problem of Venereal Disease among the Troops in Britain during World War I". In B. Bond and I. Roy, eds. War and Society. Vol. 2. London \& New York: Holmes and Meier, I977.

Carr, Cecil T. Delegated Legislation: Three Lectures. Cambridge: U. P., I92I.

Ceadel, Martin. Semi-Detached Idealists: he British Peace Movement and Inter- national Relations, I854-1945. Oxford: U. P., 2000.

Clark, Ronald W. The Life of Bertrand Russell. London: Jonathan Cape and Weidenfeld \& Nicolson, 1975.

Cline, Catherine. E. D. Morel, i8731924: the Strategies of Protest. Belfast: Blackstaff, I980.

Cosgrove, Richard. The Rule of Law: Albert Venn Dicey, Victorian furist. London: Macmillan, I980.

Daily News and Leader. "The World We Live In”, 2 Dec. I9I4, p. 4.

Delany, Paul. "Russell's Dismissal from Trinity: a Study in High Table Politics". Russell 6 (I986): 39-6I.

Freeden, Michael. Liberalism Divided: a 
Study in British Political Thought, I9I439. Oxford: Clarendon P., I986.

Gregory, Adrian. The Last Great War: British Society and the First World War. Cambridge: U. P., 2008.

Havighurst, Alfred F. Radical foumalist: H. W. Massingham, I860-I924. Cambridge: Cambridge U. P., I974.

Hewart, Lord. The New Despotism. London: Ernest Benn, I929.

Hopkin, Deian. "Domestic Censorship in the First World War". Fournal of Contemporary History 5 (I970): I 5I-69.

Kennedy, Thomas C. The Hound of Conscience: a History of the No-Conscription Fellowship. Fayetteville: U. of Arkansas P., I98I.

Law Fournal. "Restricted Residence", 9 Sept. I9I7, p. 447.

Marwick, Arthur. The Deluge: British Society and the First World War. London: Bodley Head, I965.

McLean, Iain. The Legend of Red Clydeside. Edinburgh: John Donald, I983.

Millman, Brock. "British Home Defence Planning and Civil Dissent, I9I7I9I8". War in History 5 (1998): 204-32.

-. Managing Domestic Dissent in First World War Britain. London: Frank Cass, 2000.

-. Pessimism and British War Policy, I9I6I9I8. London: Frank Cass, 200I.

Monk, Ray. Bertrand Russell: the Spirit of Solitude. London: Jonathan Cape, I996.

Morel, E. D. Truth and the War. London: National Labour P., I9I6.

The Morning Post. "The Pacifist at Large" I I Jan. I9I7, p. 6.

Parliamentary Debates (Commons and Lords), 5th ser. (I9I6-I8).

Rubin, G. R. "The Royal Prerogative or a Statutory Code? The War Office and Contingency Legal Planning, I885I9I4". In Richard Eales and David Sullivan, eds. The Political Context of Law. London: Hambledon P., I987.

- Private Property, Government Requisition and the Constitution, I9I4-27. London: Hambledon P., I994.

Rens 14.
Labour for Refusing to Disobey the Dictates of Conscience [the Everett Leaflet]. London and Manchester: National Labour P., I9r6; 49 in Papers I3.

—. "Adsum Qui Feci”. The Times, I7 May I9r6, p. 9; 54 in Papers I3; YF, pp. 656.

-. Rex v. Bertrand Russell. London: NoConscription Fellowship, I9I6; 56b in Papers I3.

-. Why Not Peace Negotiations? London and Manchester: National Labour P., I9I6; 6I in Papers I3.

-. "Bertrand Russell and the War Office". The Manchester Guardian, 27 Sept. I9r6, p. 6; 70 in Papers I3.

-. "Mysterious Girl Brings Russell's Peace Plea Here". The New York Times, 23 Dec. I9r6, pp. I, 3; 2 in Papers I4; YF, pp. 73-7.

—. "For Conscience Sake". The Independent, New York, 89 (I5 Jan. I9I7): IOI-3; 6 in Papers $\mathrm{I} 4$.

-. "The Pacifist at Large". The Morning Post, I5 Jan. I9I7, p. 8; 7 in Papers I4; YF, pp. 77-8.

-. "Imperialist Anxieties". The Tribunal, no. 72 (30 Aug. I9I7): 2; 65 in Papers I4.

-. "A New Tribunal for Gaol Delivery". The Tribunal, no. 83 (I5 Nov. I9I7): 2; 8I in Papers I4.

-. "The New Dictatorship of Opinion". Ts./ms., Nov. I9I7 (RA2 220.0II92I); 82 in Papers I4.

-. "Who Is the British Bolo?" The Tribunal, no. 84 (22 Nov. I9I7): $2 ; 83$ in $\mathrm{Pa}$ pers $\mathrm{I} 4$.

-. "Boloism in Power". The Tribunal, no. 85 (29 Nov. I9I7): 2; 84 in Papers I4.

-. "The German Peace Offer". The Tribunal, no. 90 (3 Jan. I9I8): I; 92 in $\mathrm{Pa}$ pers $\mathrm{I} 4 ; Y F$, pp. 8I-3.

-. "The Bolsheviks and Mr. Lloyd George". The Tribunal, no. 9I (Io Jan. I9I8): 2; 93 in Papers I4.

—. "Draft of Defence". Ts. (photocopy), Feb. I9I8. RA Rec. Acq. 27I; 95 in $\mathrm{Pa}-$ pers I4. 
-. SLBR 2.

-. Papers I2, 13, I4, 28, 29.

-. Papers 26 (forthcoming).

-. A Pacifist at War: Letters and Writings of Bertrand Russell, I9I4-I8. Ed. Nicholas Griffin. Nottingham: Spokesman, 20I4.

-. The Brixton Letters. Ed. Kenneth Blackwell, Andrew G. Bone, Nicholas Griffin, Sheila Turcon. 2018. $C L B R$, russell-letters.mcmaster.ca.

SAmuel, Herbert. The War and Liberty and an Address on Reconstruction. London: Hodder \& Stoughton, I9I7.

Sanders, M.L., and Philip Taylor. British Propaganda during the First World War, I9I4-19I8. London: Macmillan, I982.

Simpson, A. W. Brian. In the Highest Degree Odious: Detention without Trial in Wartime Britain. Oxford: Clarendon P., 1992.

Stevenson, David. With Our Backs to the Wall: Victory and Defeat in I9I8. Cambridge, MA: Belknap P. of Harvard U. P., 2OII.

-. 1917: War, Peace, and Revolution. Oxford: U. P., 2017.

Stubis, J. O. "Lord Milner and Patriotic Labour, 1914-1918". English Historical Review 87 (1972): 717-54.
The Times. "Law Report, May 22", 23 May I9I6, p. 3.

—. "Mr. Bertrand Russell Sentenced", II Feb. I9I8, p. 2.

The Tribunal. "The Result of the Government Prosecution", no. Io (25 May I9I6): I.

—. "Our Prosecution", no. 96 (I4 Feb. I918): I.

Thomson, Basil. The Scene Changes. New York: Doubleday, 1937.

Vellacott, Jo. Conscientious Objection: Bertrand Russell and the Pacifists in the First World War. Nottingham: Spokesman, 2015. Ist ed., I980.

Wasserstein, Bernard. Herbert Samuel: a Political Life. Oxford: Clarendon P., I992.

Webb, Beatrice. The Diary of Beatrice Webb. Vol. 3: "The Power to Alter Things", 1905-1924. Ed. Norman and Jeanne Mackenzie. Cambridge, Mass.: Harvard U. P., I984.

Western Mail, Cardiff. "Called a Traitor", 7 July I916, p. 3.

White, Stephen. "Soviets in Britain: the Leeds Convention of I9I7". International Review of Social History I9 (1974): I65-93. 